\title{
Gene Expression Patterns in Near Isogenic Lines for Wheat Rust Resistance Gene Lr34/Yr18
}

\author{
S. H. Hulbert, J. Bai, J. P. Fellers, M. G. Pacheco, and R. L. Bowden
}

First, second, and fourth authors: Department of Plant Pathology, Kansas State University, Manhattan 66506; and third and fifth authors: U.S. Department of Agriculture-Agricultural Research Service, Plant Science and Entomology Research Unit, Manhattan, KS 66506. Accepted for publication 3 March 2007.

\begin{abstract}
Hulbert, S. H., Bai, J., Fellers, J. P., Pacheco, M. P., and Bowden, R. L. 2007. Gene expression patterns in near isogenic lines for wheat rust resistance gene Lr34/Yr18. Phytopathology 97:1083-1093.

The Lr34/Yr18 resistance gene provides durable, adult-plant, slow rusting resistance to leaf rust, yellow rust, and several other diseases of wheat. Flag leaves may exhibit spontaneous leaf tip necrosis and tips are more resistant than leaf bases. Despite the importance of this gene, the mechanism of resistance is unknown. Patterns of expression for 55,052 transcripts were examined by microarray analysis in mock-inoculated flag leaves of two pairs of wheat near isogenic lines for Lr34/Yrl8 (Jupateco 73S/Jupateco 73R and Thatcher/Thatcher-Lr34). The Thatcher isolines were also examined for patterns of expression after inoculation with leaf rust. Mock-inoculated leaf tips of resistant plants showed up-regulation of
\end{abstract}

ABSTRACT
57 transcripts generally associated with ABA inducibility, osmotic stress, cold stress, and/or seed maturation. Several transcripts may be useful as expression markers for $\mathrm{Lr} 34 / \mathrm{Yr}$ r 8 . Five transcripts were also up-regulated in resistant leaf bases. The possible role of these transcripts in resistance is discussed. In mock-inoculated plants, pathogenesis-related (PR) proteins were not up-regulated in resistant flag leaves compared with that in susceptible flag leaves. In inoculated plants, the same set of PR proteins was up-regulated in both resistant and susceptible flag leaves. However, expression was often higher in resistant plants, suggesting a possible role for $L r 34 / Y r 18$ in priming of defense responses.

Additional keywords: green island effect, race nonspecific resistance, stripe rust.
Yield stability of wheat is constantly challenged by a number of biotic and abiotic stress factors. Rust diseases, including leaf rust (Puccinia triticina Eriks.), yellow or stripe rust (P. striiformis Westend.), and stem rust (P. graminis Pers.:Pers.), are globally the most important foliar diseases of wheat. Genetic resistance is the preferred method for controlling all three rusts and dozens of resistance genes have been reported for each rust species $(22,33)$. However, wheat is cultivated in huge acreages which provide many opportunities for emergence of new pathotypes that can overcome the resistance genes deployed by breeders. The breakdown of resistance in popular cultivars leaves few options in regions where fungicide treatments are not possible or economically feasible. In addition, the deployment of new resistance genes is a long process, often relying on introgression from related species. Consequently, most wheat improvement programs are seeking more durable resistance strategies to protect against rust diseases.

For typical resistance genes, the mechanism of resistance and the basis of race specificity are due to gene-for-gene interactions between host resistance genes ( $R$-genes) and pathogen avirulence (Avr) genes. Factors thought to influence durability of such resistance include the size and genetic plasticity of pathogen populations (31), effects of gene combinations or pyramids (43), the physiological cost of losing the corresponding Avr gene for the pathogen $(2,26)$, and the level of selection pressure conferred by the resistance gene (27). Various strategies have been proposed to prolong the usefulness of $R$-genes (31).

Corresponding author: R. L. Bowden; E-mail address: robert.bowden@gmprc.ksu.edu

doi:10.1094/PHYTO-97-9-1083

This article is in the public domain and not copyrightable. It may be freely reprinted with customary crediting of the source. The American Phytopathological Society, 2007.
Some disease resistance genes, like the mlo powdery mildew resistance gene of barley, have nonspecific effects and are apparently durable because they are not dependent on the recognition of a single $A v r$ gene product from the pathogen $(38,59)$. A few rust resistance genes have emerged among the many studied that appear to be associated with nonspecific durable resistance. The most well-known of these is the Lr34/Yrl8 wheat rust resistance gene $(12,22)$.

Several characteristics distinguish Lr34/Yr18 from many other rust resistance genes. First, its effect is nonspecific; that is, no rust pathotypes have been shown to be completely virulent on lines carrying Lr34/Yrl8 (13,22,51). Rubiales and Niks (42) reported that $L r 34 / Y r 18$ conditions prehaustorial resistance and is associated with reduced intercellular hyphal development but not with a hypersensitive response or papilla formation. It increases the latent period, decreases the number of pustules per unit area, and decreases pustule size as components of a slow rusting phenotype $(10,42,50)$. These effects are greater at temperatures below $25^{\circ} \mathrm{C}$, and the expression of resistance in flag leaf apices is greater than in leaf bases. Although it is considered an adult-plant gene, subtle effects of $\operatorname{Lr} 34 / \mathrm{Yr} 18$ can also be detected at younger growth stages $(48,50)$. The effect of $\operatorname{Lr} 34 / \mathrm{Yr} 18$ is additive or synergistic with other minor or major genes $(15,51)$.

The most unusual characteristic of this gene is its apparent pleiotropism. It confers adult-plant resistance to both leaf rust and stripe rust $(32,46)$ and these two effects have never been separated by recombination (53). The $L r 34 / Y r 18$ locus has also been associated with tolerance or resistance to other diseases, including Barley yellow $d$ warf virus $(B d v 1,47)$, powdery mildew (53), and stem rust (12,30). $\operatorname{Lr} 34 / \mathrm{Yr} 18$ is also completely linked with a gene conferring leaf tip necrosis in some environments (Ltn1; 45,49).

The peculiar characteristics of $\operatorname{Lr} 34 / \mathrm{Yr} 18$ strongly suggest that it conditions an unusual mechanism of resistance. Based on fine mapping studies, Bossolini et al. (4) suggested the possible in- 
volvement of a pectate lyase gene in resistance conferred by Lr34/Yr18. Rosewarne et al. (41) associated a $\beta 1$-proteasome subunit with resistance conferred by $L r 46 / Y r 29$, another wheat slow rusting gene (52). The broad spectrum of resistance and lack of race specificity are reminiscent of systemic acquired resistance (SAR) associated with expression of pathogenesis-related (PR) proteins (57). The leaf tip necrosis and higher resistance of leaf tips are suggestive of accumulation of autotoxic and/or antimicrobial compounds. Considering the increasing dependence on Lr34/Yrl 8 and other slow rusting genes for durable rust resistance (51), it is essential to obtain a greater understanding of its mechanism of resistance.

The present analysis was initiated to identify gene expression patterns and possible defense processes regulated by $L r 34 / Y r 18$ using microarray analysis. We used two pairs of near isogenic lines for Lr34/Yrl8 (Thatcher/Thatcher-Lr34 and Jupateco 73S/ Jupateco 73R) to help reduce genetic background effects unrelated to $\operatorname{Lr} 34 / \operatorname{Yr} 18$. We tested both inoculated and mock-inoculated flag leaves to identify possible induced and constitutive defense mechanisms. We examined flag leaf tips and bases separately because leaf tips are more resistant than bases and leaf tips often display necrosis in $\operatorname{Lr} 34 / \mathrm{Yr} 18$ plants. We report evidence that $L r 34 / Y r 18$ is associated with expression of a set of abiotic stress and/or seed maturation genes not usually associated with pathogen defense reactions.

\section{MATERIALS AND METHODS}

Plant material. Two pairs of spring habit near isogenic lines (hereafter referred to as isolines) for $\operatorname{Lr34/Yrl8}$ were used: Thatcher/Thatcher-Lr34 and Jupateco 73S/Jupateco 73R. ThatcherLr34 (R.L.6058) containing Lr34/Yrl8 was derived from PI 58548 backcrossed six times to Thatcher (12). Jupateco $73 \mathrm{~S}$ (without Lr34/Yr18) and Jupateco 73R (with Lr34/Yr18) were near isogenic selections from the Mexican cv. Jupateco 73 $(49,50)$.

The Thatcher and Jupateco isoline pairs were grown 6 months apart as separate experiments. For each isoline pair, the experiment was a factorial design with two factors (resistant/susceptible isoline and inoculated/mock-inoculated) and three replications. Experimental units were single plants grown in 4-liter pots in pasteurized silt-loam/peat/coarse perlite soil mix (12:55:3, $\mathrm{vol} / \mathrm{vol} / \mathrm{vol}$ ) with $2 \%(\mathrm{wt} / \mathrm{wt}$ ) gypsum. Pots were watered daily to maintain soil moisture near field capacity. Plants were grown in a $36 \mathrm{ft}^{2}$ growth chamber (Conviron PGW-36) under $15^{\circ} \mathrm{C}$ night/ $20^{\circ} \mathrm{C}$ day $\left( \pm 1^{\circ} \mathrm{C}\right)$ with a $16 \mathrm{~h}$ photoperiod and approximately $500 \mu \mathrm{mol} \mathrm{m} \mathrm{m}^{-2} \mathrm{~s}^{-1}$ photosynthetically active radiation at the top of the canopy. Relative humidity varied from approximately $70 \%$ during the day to $90 \%$ at night. Pots were fertilized at planting with $5 \mathrm{~g}$ of 14-14-14 Osmocote (The Scotts Company, Marysville, $\mathrm{OH})$ per pot and thereafter every 2 weeks with $0.5 \mathrm{~g}$ of 15 30-15 Miracle-Gro All Purpose Plant Food per pot (Scott's Miracle-Gro Products, Inc.) and $0.1 \mathrm{ml}$ of Fertilome Chelated Liquid Iron and Other Micronutrients (Voluntary Purchasing Groups, Inc., Bonham, TX) per pot. No pest problems were detected during the experiments and no pesticides were applied.

Thatcher isolines were uniformly and heavily inoculated with the $P$. triticina race MFBL (see literature citation 23 for race descriptions) suspended in Soltrol 170 light oil (Chevron Phillips Chemical Company, The Woodlands, TX). Thatcher and ThatcherLr34 do not contain effective major genes against this race. Mock-inoculated plants were sprayed only with Soltrol oil. Inoculation was done at 6:00 p.m., and the inoculated and mock-inoculated plants were then incubated overnight in a mist chamber in a greenhouse at $20 \pm 3^{\circ} \mathrm{C}$ with $100 \%$ relative humidity for $14 \mathrm{~h}$. The plants were returned to the growth chamber until sampling at 9:00 a.m. on the third day after inoculation, which was $48 \mathrm{~h}$ after removal from the mist chamber.
One or two flag leaves were harvested from tillers of single plants at the anthesis stage (Feekes stage 10.51 to 10.53). Necrotic and chlorotic portions of the leaf tip were carefully excised and discarded. The apical half (hereafter referred to as tip) and the basal half (hereafter referred to as base) of the leaves were handled separately and immediately frozen with liquid nitrogen and stored at $-80^{\circ} \mathrm{C}$. Each isoline-treatment combination had three biological replications. After sampling was completed, unsampled tillers of mock-inoculated plants were inoculated with a virulent race and the expected resistance phenotypes were verified. Jupateco isolines were inoculated with race MQNS, which was chosen to overcome $\operatorname{Lr} 17$.

RNA isolation and microarray procedure. Frozen leaf tissue was ground in liquid nitrogen and immediately suspended in TRIzol reagent, and total RNA was isolated following the manufacturer's suggested protocol (Invitrogen, Carlsbad, CA). Isolated RNA was further purified with Qiagen (Valencia, CA) RNeasy columns. Five micrograms of total RNA was used for first-strand cDNA synthesis using Affymetrix (Santa Clara, CA) One-Cycle Target Labeling and Control Reagent. Second-strand cDNA and cRNA synthesis/labeling were performed using the same kit following the manufacturer's instructions. Fifteen micrograms of cRNA was fragmented and used for chip hybridization. RNA quality was tested using an Agilent Bioanalyzer 2100 (Agilent Technologies, Palo Alto, CA).

GeneChip Wheat Genome Array. The GeneChip (Affymetrix) Wheat Genome Array contains 61,127 probe sets representing 55,052 transcripts predicted to be unique. Each probe set is made up of 11 matching and 11 mismatching 25-mer oligonucleotides that provide multiple independent estimates of signal and background hybridization levels. Probe sets with different numbers after the decimal usually denote related unigenes. Alphabetic suffixes denote whether probe sets may contain probes that are perfect matches to more than one exemplar. Some transcripts may be monitored by more than one probe set and some probe sets may match more than one transcript. The sequence information comes from publicly available expressed sequence tag (EST) sequences from wheat (Triticum aestivum) and wheat relatives (T. monococcum, T. turgidum, and Aegilops tauschii). The available wheat sequences included more than 34,000 ESTs from libraries made from tissues treated with high or low temperatures or stressed by drought or salt treatment. They also included more than 42,000 sequences from tissues treated with various plant pathogens. T. aestivum expression controls include ubiquitin, $18 \mathrm{~S}$ rRNA, glucose-6-phosphate dehydrogenase, cytochrome P450 CYP86, sucrose synthase, actin, elongation factor- $1 \alpha$, and glyceraldehyde-3-phosphate dehydrogenase (GAPDH).

The Thatcher experiment used a total of 24 microarray chips. However, only 12 microarray chips were available for the Jupateco experiment and therefore only the mock-inoculated tissue was used. The allocation of all 36 microarray chips is described in Table 1.

Data analysis. After alignment of the image settings for each chip, raw data were extracted and marked as "present" (well above the background), "marginal", or "absent" (similar to, or below the background) under default settings. The average signal intensity of each chip was scaled to 500 and analyzed using GeneSpring GX 7.3.1 software (Agilent Technologies). The data were prenormalized to the 50th percentile per chip and then normalized based on per-gene normalization with the median method, from which the signal of each gene in a particular sample was divided by the median signal of the same gene in all samples. Microarray data were deposited in the NCBI Gene Expression Omnibus (available online from the National Center for Biotechnology Information [NCBI] website) under accession nos. GSM143490 through GSM143526.

Data from the Jupateco isolines, mock-inoculated Thatcher isolines, and inoculated Thatcher isolines were analyzed separately 
for the effect of resistance on gene expression. Comparisons were made between samples from the same tissue type. For each probe set, one-way analysis of variance (ANOVA) was performed with three biological replicates to test the effect of resistant versus susceptible isolines. Fold changes were calculated as resistant divided by susceptible values. Probe sets were retained that were statistically significant $(P \leq 0.05)$, showed greater than 1.5 -fold change, and those that were marked as present by the GeneSpring software in at least two of six chips involved in a given comparison.

Data from the Thatcher-Lr34 and Thatcher isolines were analyzed separately for the effect of inoculation on gene expression. Comparisons were made between samples from the same tissue type. Fold changes were calculated as inoculated divided by mock-inoculated values. Probe sets were retained that were statistically significant $(P \leq 0.05)$, showed greater than a fivefold change, and those that were marked as present by the software in at least two of six chips involved in a given comparison.

Initial annotations of the probe sets on the arrays were performed using HarvEST software (provided online by the University of California). This provided a consensus sequence for each transcript (unigene) that was assembled from ESTs that were predicted to belong to that transcript. Each unigene sequence was used to search for homologous sequences of the GenBank NR and EST databases by both nucleotide (blastn) and predicted protein (tblastx). Predicted unigenes with regions of low quality sequence data were scrutinized to determine if they may represent chimeric sequences. If so, the distribution of probes on ESTs was used to identify the best homologs for annotation purposes. Sequences with significant matches to predicted proteins from other species with no known function were designated as predicted proteins and those with no significant matches $(P>1 \mathrm{e}-05)$ were considered as having no homology to characterized genes.

\section{RESULTS}

Rust resistance phenotypes. Inoculated flag leaves showed no symptoms at the time of sampling for RNA extraction at $48 \mathrm{~h}$ after removal from the mist chamber. Some flag leaves of resistant lines showed some leaf tip necrosis, but the necrosis was confined to the extreme tips. The first chlorotic flecks associated with rust infection were observed on susceptible lines at approximately $72 \mathrm{~h}$ after removal from the mist chamber. The first erupted pustules were observed on susceptible lines at approximately $120 \mathrm{~h}$ after removal from the mist chamber.

At 9 days after inoculation (192 $\mathrm{h}$ after removal from the mist chamber), inoculated flag leaves of resistant lines showed no rust

TABLE 1. Allocation of wheat microarray chips to mock-inoculated or inoculated leaf tips or leaf bases of resistant or susceptible isolines in Thatcher or Jupateco backgrounds

\begin{tabular}{llllc}
\hline $\begin{array}{l}\text { Cultivar } \\
\text { background }\end{array}$ & $\begin{array}{l}\text { Inoculation } \\
\text { treatment }\end{array}$ & $\begin{array}{l}\text { Leaf } \\
\text { tissue }^{\mathrm{a}}\end{array}$ & Isoline $^{\mathrm{b}}$ & $\begin{array}{c}\text { Microarray } \\
\text { chips }^{\mathrm{c}}\end{array}$ \\
\hline Thatcher & Mock-inoculated & Tip & $\begin{array}{l}\text { Resistant } \\
\text { Susceptible }\end{array}$ & 3 \\
& Base & $\begin{array}{l}\text { Resistant } \\
\text { Susceptible }\end{array}$ & 3 \\
& & Tip & Resistant & 3 \\
& & & Susceptible & 3 \\
& & Base & Resistant & 3 \\
& & & Susceptible & 3 \\
Jupateco & Mock-inoculated & Tip & Resistant & 3 \\
& & & Susceptible & 3 \\
& & Base & Resistant & 3 \\
& & & Susceptible & 3
\end{tabular}

\footnotetext{
a Tip indicates the apical half of the flag leaf during anthesis; base indicates basal half.

b Resistant isolines contain $\operatorname{Lr} 34 / \mathrm{Yr} 18$ rust resistance gene.

${ }^{\mathrm{c}}$ Each microarray chip was hybridized to separate biological replicates.
}

development and flag leaves of susceptible lines showed heavy development of leaf rust (Fig. 1). Resistant lines showed significant leaf tip necrosis in both the inoculated and mock-inoculated treatments. A few Thatcher flag leaves showed slight leaf tip necrosis.

At 15 days after inoculation, the apical halves of the flag leaves of resistant lines showed highly resistant reactions while the basal halves showed a moderate level of resistance; uredinia were fewer, smaller, and slower to develop than in the susceptible isolines (Fig. 1). Leaf tip necrosis on resistant plants was more pronounced in both the inoculated and mock-inoculated treatments at day 15 than at day 9. A few susceptible flag leaves showed slight leaf tip necrosis. A few mock-inoculated flag leaves of Thatcher isolines showed a few leaf rust pustules due to contamination during the inoculation process.

Microarray data quality. High quality data were obtained from all 36 microarray chips. Scaling factors ranged from 3.5 to 6.9 with an average of 4.9 , and percent present calls ranged from 39.2 to $44.3 \%$ with an average of $41.6 \%$. Noise ranged from 1.3 to 2.2 and averaged 1.7. T. aestivum control transcripts that showed the most stable signal intensities across treatments in the experiment were actin (Fig. 2A), elongation factor-1 $\alpha, \mathrm{GAPDH}$, and ubiquitin (Fig. 2B).

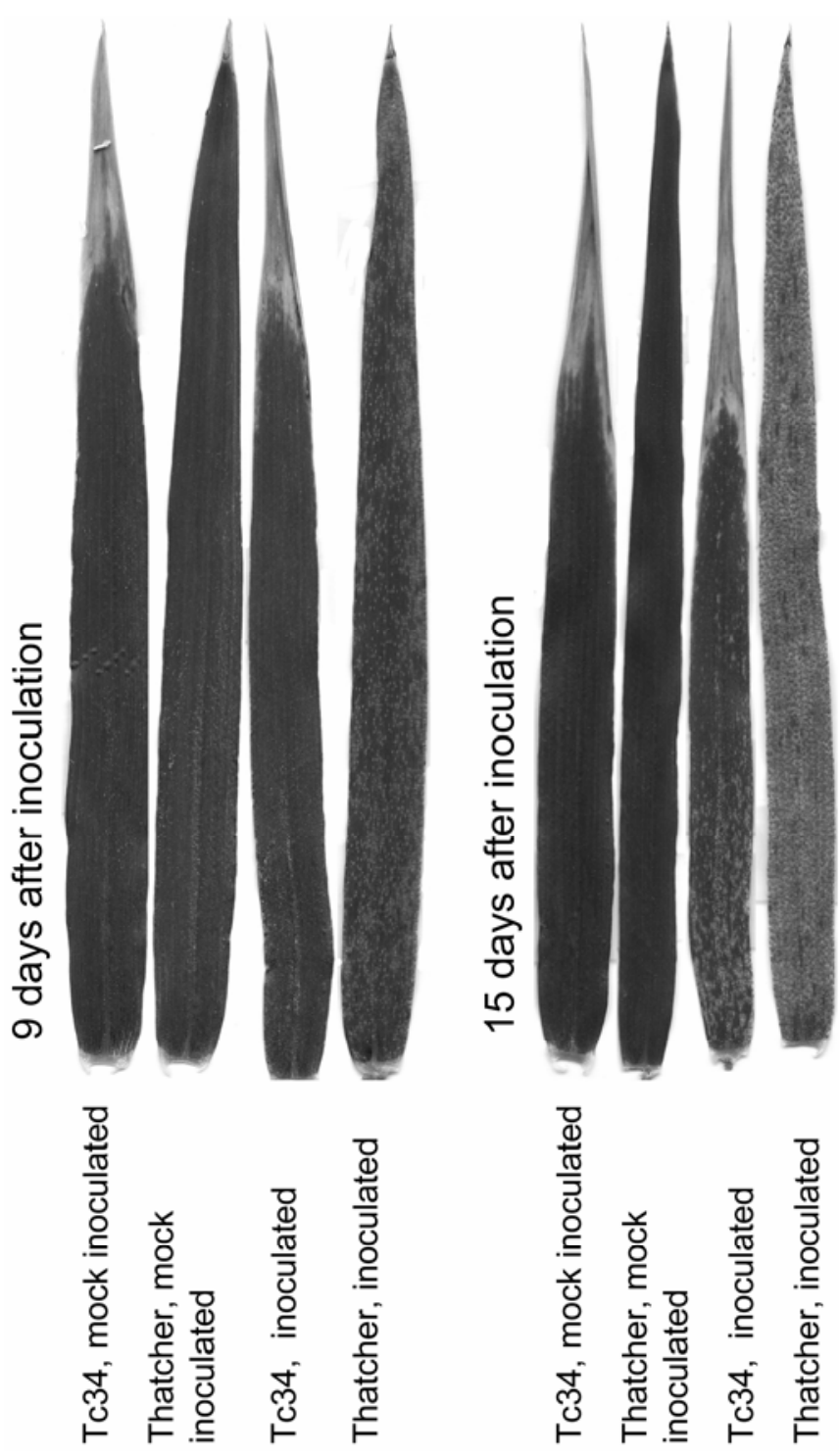

Fig. 1. Resistance phenotypes of inoculated or mock-inoculated ThatcherLr34 (Tc34) and Thatcher at 9 and 15 days after inoculation. 

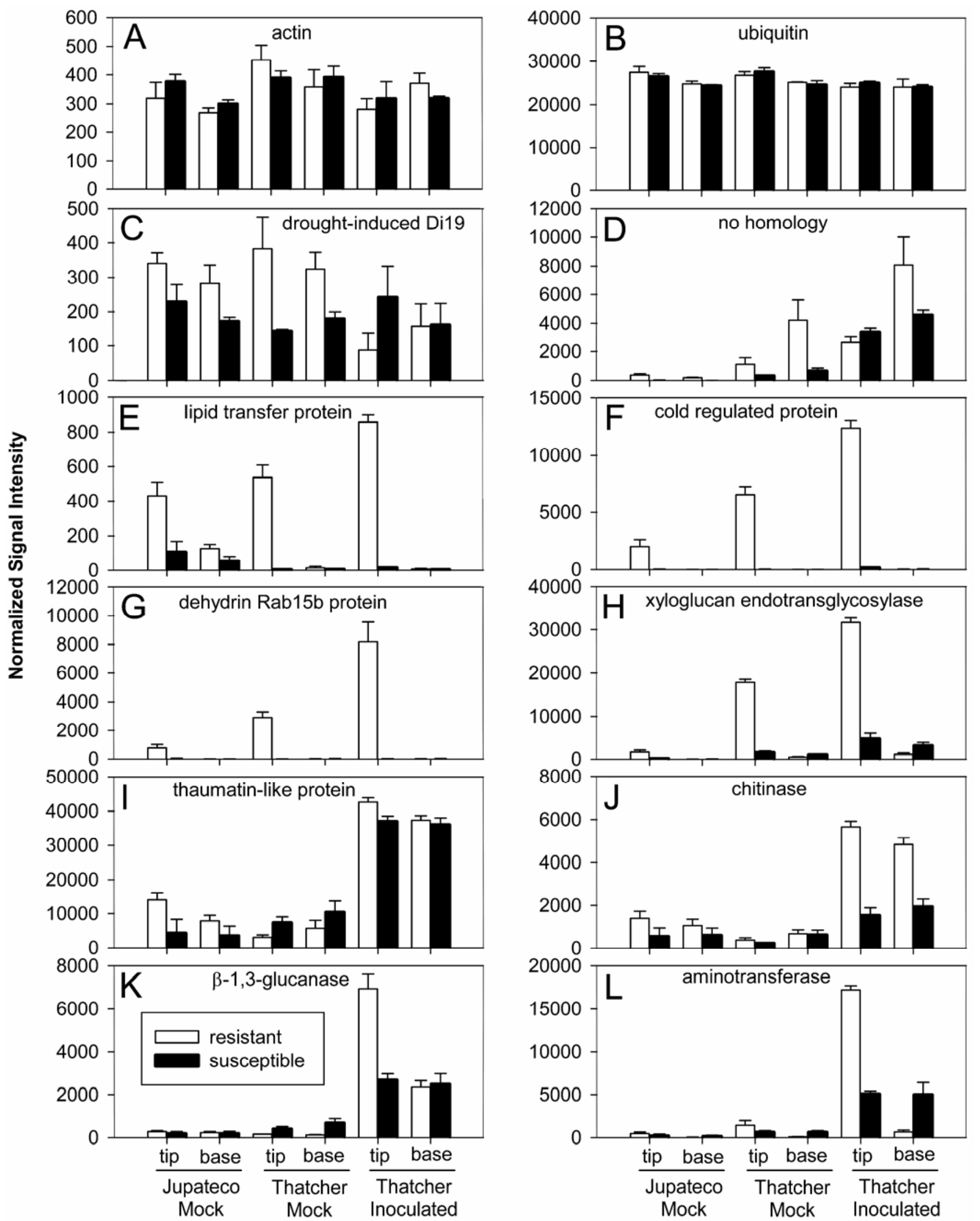

Fig. 2. Normalized signal intensities of Affymetrix Wheat GeneChip probe sets in tips or bases of flag leaves of mock-inoculated Jupateco isolines, mockinoculated Thatcher isolines, and rust-inoculated Thatcher isolines with Lr34/Yr18 (white bars) or without Lr34/Yr18 (black bars). A, AFFX-Ta-actin-M_at; B, AFFX-Ta_Ubiquitin_3_at; C, Ta_6567.3.A1_X_at; D, Ta_14836.1.A1_at; E, Ta_28327.A1_at; F, Ta.13183.1.S1_s_at; G, Ta.2638.1.S1_at; H, Ta.13337.1.S1_at; I, Ta.959.1.S1_at; J, Ta.2278.1.S1_x_at; K, Ta.8584.1.S1_at; and L, TaAffx.21593.1.S1_at. Error bars represent standard error of the mean of three biological replications. 
Genes up-regulated in mock-inoculated Lr34/Yr18 lines. Comparisons of gene expression in the mock-inoculated resistant and susceptible isolines showed evidence of extensive differences in flag leaf gene expression without pathogen challenge. The number of genes that showed a significantly higher $(P \leq 0.05$ and at least 1.5 -fold change) level of expression in $L r 34 / Y r 18$ isolines was calculated for the tip and base for each of the two isoline pairs. In the tips of the Thatcher isoline flag leaves, 829 genes showed significantly more transcript in Thatcher-Lr34 than in Thatcher and 163 showed at least fivefold more transcript. In contrast, only 470 genes were up-regulated more than 1.5 -fold in the Thatcher-Lr34 line in the basal half of the leaf and only 11 were up-regulated more than fivefold. A similar trend was observed in the Jupateco isolines but fewer genes were significantly affected in this experiment. There were 299 genes that were at least 1.5 -fold more highly expressed in the leaf tips with only 33 showing more than fivefold higher expression. Only 149 and 17 showed more than 1.5- or fivefold higher expression in the leaf bases, respectively.

To reduce the false discovery rate attributable to experimental error or imperfect isogenicity of the isolines, the intersection of the sets of significant transcripts from mock-inoculated Thatcher and Jupateco isolines was examined. Fifty-seven transcripts were up-regulated at least 1.5-fold in the resistant leaf tips of both the Thatcher and Jupateco isolines, while only seven transcripts were consistently up-regulated in both experiments in the leaf bases (Table 2). Data from inoculated plants were not used for data filtering in this table, but are presented for comparison. The genes that were consistently up-regulated in resistant mock-inoculated leaves showed very similar patterns of up-regulation in inoculated resistant leaves (Table 2).

Many of the transcripts with increased expression in resistant leaf tips putatively encode stress-related proteins (Table 2, Fig. 2C to $\mathrm{H})$. These included transcripts associated with desiccation, like dehydrins, and other proteins involved in seed maturation. Other gene products associated with osmotic stress due to drought or salt include pyrroline-5-carboxylate synthetase which is involved in proline synthesis $(40,60)$, a putative galactinol synthase which is involved in synthesis of raffinose family oligosaccharides $(7,62)$, and a gene with homology to the drought-induced Arabidopsis Di19 (17) protein. Other genes encoded proteins induced by cold stress or acclimation. These include genes found to be cold-regulated in barley (Ta.13183.1 [8]) or wheat (Ta.13380.1 [14]; TaAffx.80153.1 [56]; Ta.4222.1 [19]). Also up-regulated was the Ta.129.1 gene that codes for the ABA inducible plasma membrane protein PM19, which is also associated with cold tolerance (21), and another very closely related gene, Ta.14259.1. Other up-regulated transcripts represented a variety of metabolic processes, some of which are probably stress-related. These include transcripts for two proteinases and a proteinase inhibitor, and two xyloglucan endotransglycosylases, which are likely involved in cell wall modification. Possibilities for up-regulated regulatory or signaling proteins include three lipid transfer proteins (LTPs), three transcription factors, and a protein phosphatase 2C-like transcript.

Genes down-regulated in mock-inoculated $\mathrm{Lr34/Yr18}$ lines. Only a few genes were consistently down-regulated in mockinoculated tissues and they were typically down-regulated only approximately twofold (Table 3). Only the Ta.12091.1 transcript was found to be down-regulated in both the Thatcher and Jupateco isolines in both the tips and bases of the leaves. The function of this gene is unknown. Five other transcripts were downregulated in the mock-inoculated leaf bases but not the leaf tips. The CPRD2-like FAD-linked oxidoreductase and two xyloglucan endotransglycosylases were down-regulated in the bases but upregulated in the leaf tips.

Changes in gene expression induced by rust inoculation. The effect of rust inoculation on gene expression in Thatcher and
Thatcher-Lr34 in leaf tips and leaf bases was examined by comparing inoculated and mock-inoculated treatments. In the ThatcherLr34 leaf tips, there were 1,478 genes that appeared significantly different $(P<0.05)$ and at least twofold higher expression in rustinfected tissue than in mock-inoculated tissue. Similarly, there were 1,610 genes with twofold higher expression in the rustinfected Thatcher leaves. In the basal halves of the leaves, 425 appeared significantly $(P<0.05$ and twofold) rust-induced in the Thatcher-Lr34 leaves and 610 in the Thatcher leaves. Because of the large numbers of genes examined, a more stringent criterion was used to create a list of rust-induced genes (Table 4), including only genes that were significantly up-regulated and showed at least a fivefold difference in at least three of the four tissues examined (leaf base or tip in Thatcher-Lr34 or Thatcher). The resulting list of putative rust-induced transcripts contained 59 unigenes (Table 4) including typical PR proteins such as chitinases, glucanases, thaumatin-like proteins, genes involved in detoxification like cytochrome P450s, and genes involved in phenylpropanoid biosynthesis.

Only two of the transcripts found to be up-regulated in mockinoculated resistant lines with $\operatorname{Lr} 34 / \mathrm{Yr} 18$ (Table 2) were among the most highly up-regulated by rust infection (Table 4), including a predicted protease inhibitor (TaAffx.132498.1) and a predicted aminotransferase (TaAffx.21593.1, Fig. 2L), which is probably GABA transaminase. Several of the other $\operatorname{Lr} 34 / \mathrm{Yr} 18$-associated genes appeared moderately up-regulated by rust infection, showing at least twofold induction over the mock-inoculated control tissues in at least three of the four tissues examined (data not shown). These include one of the predicted dehydrins (Ta.13255.1), a xyloglucan endotransglycosylase (Ta.13337.2), a glutamate dehydrogenase (Ta.1870.1), two aldehyde dehydrogenases, (Ta.2107.1 and Ta.2107.3), an aldo/keto reductase (Ta.26922.1), a beta-D-glucan glucohydrolase (Ta.27751.5), and two unknown proteins (Ta.14224.1 and Ta.14836.1).

Both resistant and susceptible flag leaves expressed essentially the same set of up-regulated PR proteins and defense-related proteins after inoculation (Table 4). On average, the difference in response between inoculated and mock-inoculated tissues was 2.9-fold higher ( $t$ test, $P<0.0001)$ in the Thatcher-Lr34 leaf tips and 2.1-fold higher ( $t$ test, $P<0.0001)$ in Thatcher-Lr34 leaf bases than in Thatcher (Table 4). However, this broad view overlooks the fact that several different patterns of expression were exhibited by the transcripts in Table 4 . One group was strongly rust-responsive but was not affected significantly by resistance. This group included Ta.959.1 (thaumatin-like protein, Fig. 2I), Ta.2784.1 (chitinase), Ta.21342.1 (chitinase), as well as TaAffx.83275.1, TaAffx.83275.3, Ta.27327.1, and TaAffx.31943.1 (all PR-1 proteins). Another group was strongly rust-responsive, but resistant leaf tips and bases responded much more strongly. This group included Ta.2278.1 (chitinase, Fig. 2J), Ta.2278.2 (chitinase), Ta.2278.3 (chitinase), Ta5810.1 (Wali6/Wali3-like), and Ta.8653.1 (no homology). A third group was most strongly rust-responsive in resistant tips. This group consisted of Ta.8584.1 (glucanase, Fig. 2K), Ta.24475.1 (glucanase), Ta.2690.1 (glutamine-dependent asparagine synthetase), and TaAffx.128418.43 (chitinase). The fourth group was similar, but seemed to be upregulated in resistant tips and down-regulated in resistant leaf bases. It contained Ta.21593.1 (aminotransferase, Fig. 2L), TaAffx.108909.1 (aminotransferase), and Ta.22693.2 (predicted protein).

Two genes were highly down-regulated by rust infection using the same criterion as for the up-regulated genes. One transcript showed homology to cysteine proteinases (Ta.29534.1). The other down-regulated transcript (TaAffx.100446.1) was predicted to code for ACC oxidase (Table 4).

Wheat chemically induced genes. Five genes were previously identified as being highly induced by SAR-inducing chemicals in wheat (16). Treatment with benzothiadiazole (BTH) provided 
TABLE 2. Genes up-regulated in resistant isolines with $L r 34 / Y r 18$ in both Thatcher and Jupateco backgrounds

\begin{tabular}{|c|c|c|c|c|c|c|c|}
\hline \multirow{3}{*}{$\begin{array}{l}\text { Probe set (unigene) } \\
\text { designation }^{\mathrm{a}}\end{array}$} & \multicolumn{6}{|c|}{ Fold differences between $L r 34$ and $l r 34$ transcript levels } & \multirow[b]{3}{*}{ Description } \\
\hline & \multicolumn{2}{|c|}{$\begin{array}{l}\text { Jupateco mock- } \\
\text { inoculated }\end{array}$} & \multicolumn{2}{|c|}{$\begin{array}{c}\text { Thatcher mock- } \\
\text { inoculated }\end{array}$} & \multicolumn{2}{|c|}{$\begin{array}{l}\text { Thatcher rust- } \\
\text { inoculated }\end{array}$} & \\
\hline & $\operatorname{Tip}^{\mathrm{b}}$ & Base & Tip & Base & Tip & Base & \\
\hline Ta.2638.1.S1_at & $34.5^{\mathrm{c}}$ & & 288.2 & & 224.1 & & Dehydrin/Rab15b protein \\
\hline Ta.13255.1.S1_at & 20.9 & & 33.8 & & 15.4 & & Dehydrin \\
\hline TaAffx.128555.1.S1_at & 3.3 & & 6.9 & & 16.1 & & Dehydrin \\
\hline TaAffx.131747.1.S1_x_at & 13.51 & & 2.2 & & 3.9 & 1.6 & Dehydrin \\
\hline Ta.26049.1.S1_a_at ${ }^{\mathrm{d}}$ & 2.2 & & 21.8 & & 86.1 & & Dehydrin \\
\hline Ta.23797.1.S1_x_at & 6.1 & & 62.1 & & 51.7 & & Late embryogenesis abundant protein (LEA) \\
\hline Ta.28533.1.S1_at & 8.2 & & 15.0 & & 19.2 & & Late embryogenesis abundant protein (LEA) \\
\hline Ta.24158.1.S1_a_at & 3.2 & & 4.9 & & 6.3 & & Embryo-specific protein \\
\hline Ta.9389.1.S1_x_at & 30.0 & & 57.3 & & 23.6 & & Soybean seed maturation protein, PM41 \\
\hline Ta.9389.1.S1_at & 36.4 & & 34.8 & & 83.6 & 1.9 & Soybean seed maturation protein, PM41 \\
\hline Ta.7091.1.S1_at & 4.8 & & 17.9 & & 34.2 & & Pyrroline-5-carboxylate synthetase \\
\hline TaAffx.17365.2.A1_at & 4.6 & & 2.2 & & & & Galactinol synthase \\
\hline Ta.6567.3.A1_a_at & 1.6 & 1.6 & 2.5 & 1.8 & & & Drought-induced Di19 protein \\
\hline Ta.14259.1.S1_at & 11.3 & & 28.5 & & 86.2 & & ABA-induced plasma membrane protein \\
\hline Ta.129.1.S1_at & 3.1 & & 3.3 & & 4.7 & & ABA-induced plasma membrane protein PM 19 \\
\hline Ta.13183.1.S1_s_at & 54.8 & & 193.7 & & 109.9 & & Cold-regulated protein, phosphatidylethanolamine-binding \\
\hline Ta.13183.1.S1_x_at & 14.6 & 1.7 & 26.2 & 1.9 & 58.0 & & Cold-regulated protein, phosphatidylethanolamine-binding \\
\hline Ta.13380.1.S1_at & 2.3 & & 9.3 & & 12.7 & & Low-temperature-specific wheat gene tacr7 \\
\hline TaAffx.80153.1.S1_at & 1.9 & & 5.7 & & & & Ice recrystallization inhibition protein \\
\hline Ta.4222.1.S1_at & 2.6 & & 3.3 & & 4.8 & & Low-temperature induced membrane protein \\
\hline Ta.19158.1.A1_at & 1.9 & & 8.2 & & 5.7 & & Subtilisin-like proteinase \\
\hline Ta.3993.1.S1_at & 2.3 & & 6.8 & & 8.7 & & Nucellain- or legumain-like protease \\
\hline TaAffx.132498.1.S1_at & 1.9 & & 3.9 & & 2.5 & & Maize protease inhibitor \\
\hline Ta.11025.1.A1_at & 3.0 & & 62.5 & & 50.9 & & CPRD2-like FAD-linked oxidoreductase \\
\hline Ta.11623.2.A1_at & 1.7 & & 2.8 & & 4.3 & & BTB/POZ domain-containing protein \\
\hline Ta.13070.1.S1_at & 2.8 & & 3.2 & & 3.3 & & Type 1 nonspecific lipid transfer protein \\
\hline Ta.13070.2.S1_a_at & 2.6 & & 4.4 & & 5.5 & & Type 1 nonspecific lipid transfer protein \\
\hline Ta.28327.1.S1_x_at & 8.4 & 3.5 & 99.9 & 1.6 & 56.2 & & Type 2 nonspecific lipid transfer protein \\
\hline Ta.13337.1.S1_at & 10.3 & & 12.1 & & 6.8 & & Xyloglucan endotransglycosylase \\
\hline Ta.13337.2.S1_at & 12.8 & & 23.6 & & 14.3 & & Xyloglucan endotransglycosylase \\
\hline Ta.13337.2.S1_x_at & 9.0 & & 24.5 & & 14.9 & & Xyloglucan endotransglycosylase \\
\hline Ta.13682.1.A1_at & 4.5 & & 25.7 & & 24.5 & & Progesterone 5-beta-reductase \\
\hline Ta.1870.1.S1_a_at & 2.7 & & 3.3 & & 2.2 & & Glutamate dehydrogenase \\
\hline Ta.2107.1.S1_s_at & 3.9 & & 10.6 & & 3.9 & & Aldehyde dehydrogenase \\
\hline Ta.2107.3.S1_at & 1.9 & & 6.1 & & 4.7 & & Aldehyde dehydrogenase \\
\hline Ta.10207.1.S1_at & 2.6 & & 2.8 & & 5.7 & & Protein phosphatase $2 \mathrm{C}$-like \\
\hline TaAffx.36680.1.A1_at & 2.7 & & 2.4 & & & & Transcriptional activator \\
\hline TaAffx.122104.1.S1_at & 3.0 & & 5.0 & & 5.8 & & NAC domain transcription factor \\
\hline TaAffx.98394.1.S1_at & 2.6 & & 9.8 & & 15.7 & & $\mathrm{C} 2 \mathrm{H} 2$-type zinc finger protein \\
\hline Ta.26922.1.S1_at & 2.2 & & 4.1 & & 4.8 & & Aldo/keto reductase family \\
\hline Ta.27751.5.S1_at & 3.5 & & 7.6 & & 3.1 & & Beta-D-glucan glucohydrolase \\
\hline Ta.28012.1.S1_a_at & 2.0 & & 1.7 & & & & Potassium transporter \\
\hline Ta.29508.1.S1_at & 1.7 & & 2.0 & & 1.7 & & Branched-chain alpha-keto acid dehydrogenase subunit \\
\hline Ta.29508.3.S1_a_at & 1.5 & & 2.3 & & 2.3 & & Branched-chain alpha-keto acid dehydrogenase subunit \\
\hline Ta.8227.1.S1_at & 2.3 & & 2.5 & & 2.9 & & Cytochrome P450 \\
\hline TaAffx.21593.1.S1_at & 10.9 & & 2.2 & & 3.2 & & Aminotransferase \\
\hline TaAffx.35563.1.A1_at & 2.7 & & 14.9 & & 27.9 & & Peptide chain release factor subunit 1 \\
\hline Ta.5421.1.A1_at & & 1.7 & & 1.6 & & & Cytochrome oxidase assembly protein \\
\hline TaAffx.4531.2.S1_at & 2.3 & & 1.7 & & & & Probable membrane protein \\
\hline Ta.12896.1.S1_at & 1.6 & & 4.4 & & 4.8 & & Predicted protein \\
\hline Ta.29464.1.A1_at & 5.4 & & 2.1 & & 2.3 & & Predicted protein \\
\hline Ta.1327.1.S1_x_at & 3.0 & & 5.6 & & 3.9 & & Predicted protein \\
\hline TaAffx.12097.1.A1_at & 2.7 & & 17.5 & & 16.0 & & Predicted protein \\
\hline TaAffx.130713.1.A1_at & 4.1 & & 4.1 & & 2.5 & & Predicted protein \\
\hline TaAffx.64112.1.S1_at & 1.7 & 2.1 & 2.9 & 4.4 & & & Predicted protein \\
\hline TaAffx.79120.2.A1_at & 2.0 & & 1.7 & & & & Predicted protein \\
\hline Ta.14224.1.S1_at & 3.0 & & 4.2 & & 4.4 & & Predicted protein \\
\hline Ta.14836.1.A1_at & 25.3 & 10.6 & 2.5 & 7.4 & & 1.7 & No homology \\
\hline Ta.16163.1.S1_at & 2.0 & & 2.3 & & & & No homology \\
\hline Ta.8866.2.S1_at & 2.9 & & 2.3 & & 1.9 & & No homology \\
\hline Ta.9831.1.S1_at & 1.8 & & 1.8 & & & & No homology \\
\hline TaAffx.102050.1.S1_at & & 1.9 & & 1.6 & & & No homology \\
\hline
\end{tabular}

${ }^{a}$ Probe set designations from Affymetrix. Data include two different probe sets for the Ta.9389.1, Ta.13183.1, and Ta.13337.2 genes.

${ }^{\mathrm{b}}$ Tip indicates the apical half of the flag leaf during anthesis; base indicates basal half.

${ }^{c}$ Indicates the fold change in Lr34/Yr 18 carrying lines compared with their respective susceptible isolines. Fold change for each cultivar background, inoculation treatment, and leaf tissue was calculated separately with three replicates. Only changes of $\geq 1.5$ fold and $P \leq 0.05$ are shown.

d Unigene Ta.26049.1 appears to be chimeric. Description based on portion of unigene sampled by probe set. 
powdery mildew resistance and dramatically increased transcription of the wheat chemically induced genes, WCI-1 to WCI-5. When the transcript levels of these genes were examined in the present experiments, none of the genes was found to be significantly up-regulated by Lr34 in mock-inoculated tissues (Table 2) and expression of three of the five was not significantly up-regulated by rust inoculation in the Thatcher isolines (Table 4). The WCI-5 gene was up-regulated by rust inoculation 2.1- and 2.7fold in leaf tips of Thatcher-Lr34 and Thatcher, respectively. The WCI-3 gene, predicted to encode a sulfur-rich, thionin-like protein, was more highly expressed $(\approx 14$-fold) in rust-infected leaf tips of Thatcher-Lr34 than the corresponding tissues in Thatcher.

\section{DISCUSSION}

We used the Affymetrix Wheat GeneChip microarray to investigate the gene transcript profiles conferred by the durable, slow rusting resistance gene, $\operatorname{Lr} 34 / \mathrm{Yr} 18$. We believe this is the first report using the Wheat GeneChip to study host-parasite interactions. In general, reproducibility was excellent among biological replicates with these microarrays (Fig. 2). The high correlation of expression data from the GeneChip microarray platform with northern blots or the serial analysis of gene expression method has already been documented $(18,58)$. With 61,127 probe sets derived from 211 different EST libraries, transcriptome coverage is excellent. We concentrated on mock-inoculated leaves because previous studies indicated that resistance is prehaustorial and leaf tip necrosis occurs spontaneously in resistant leaves. By using two pairs of near isogenic lines, we were able to focus on transcripts that are reproducibly associated with resistance. By separately examining expression in leaf proximal halves (bases) and distal halves (tips), we were able to distinguish large differences in transcript abundance within portions of the same leaves. In addition to providing a baseline of transcript profiles for isolines with $\operatorname{Lr} 34 / Y r 18$, this data set is useful for generating and evaluating hypotheses about the mechanisms of resistance for this gene.

Patterns of gene expression of resistant isolines with $\mathrm{Lr} 34 / \mathrm{Yr} 18$ revealed a characteristic abiotic stress expression signature, which was observed in both mock-inoculated and rust-inoculated plants. Most members of this set of 57 up-regulated genes have been previously associated with abscisic acid (ABA) inducibility, drought/osmotic stress, cold stress, and seed maturation (Table 2). Most of these transcripts were highly up-regulated in the flag leaf tips, but not the leaf bases. This pattern correlates with the resistance phenotype since leaf tips are much more resistant than bases (Fig. 1). Typical PR proteins such as chitinases, glucanases, thaumatin-like proteins, and genes involved in phenylpropanoid biosynthesis were notably absent from the list of up-regulated transcripts in mock-inoculated leaves (Table 2).

Many of the signature transcripts showed quantitative differences between isolines, but several showed a qualitative expres- sion pattern with little or no detectable transcript in susceptible plants. These include Ta.2638.1 (dehydrin/Rab15b protein, Fig. 2G), Ta.13183.1 (cold regulated protein, Fig. 2F), Ta.9389.1 (soybean seed maturation protein PM41), and Ta.13255.1 (dehydrin). Ta.28327.1 (LTP, Fig. 2E) and Ta.13337.1 (xyloglucan endotransglycosylase, Fig. $2 \mathrm{H}$ ) show similar patterns, but they occasionally show low-level expression in susceptible plants. Ta.2638.1 and Ta.13183.1 were the two most highly up-regulated transcripts and are good candidates for qualitative expression markers for Lr34/Yr18. Although diagnostic DNA markers are available for Lr34/Yrl8 (4,25), expression markers could be very useful for comparing different slow rusting resistance genes or identifying superior alleles. The utility of these candidate expression markers needs to be tested with different cultivars, developmental stages, and times after inoculation.

An important question is whether these abiotic stress-related signature transcripts are associated with $\operatorname{Lr} 34 / \mathrm{Yr} 18$ rather than some other experimental stress factor. Plants were constantly well-watered and temperature was controlled and constantly monitored, so it is unlikely that they experienced any significant environmental stress. Lin et al. (28) reported that the light mineral oil used in rust inoculations induced expression of three thaumatin-like proteins in oats. However, in our experiments, thaumatinlike proteins and other PR proteins were not up-regulated in mock-inoculated tissues (Table 2). In any case, the abiotic stress signature genes were up-regulated mainly in leaf tips of resistant plants but not susceptible plants or resistant plant leaf bases. If a common experimental stress factor had a direct effect on abiotic stress gene expression, we would not expect to see expression only in resistant tips.

One possible explanation for the abiotic stress signature in resistant leaves is drought or osmotic stress associated with spontaneous tip necrosis. There are two reasons why this seems unlikely. First, we were careful to trim all necrotic and adjacent chlorotic tissues from leaves, so samples contained only healthy appearing tissues. Second, levels of biosynthetic transcripts for ABA, the key osmotic- and drought-stress responsive plant hormone, were not significantly changed in the resistant plants. NCED (9-cis-epoxycarotenoid dioxygenase) is an enzyme in the pathway for biosynthesis of ABA and is strongly implicated as the major rate-limiting step in leaves (44). NCED transcript levels are highly up-regulated by drought stress in both dicots and monocots $(44,54)$. NCED belongs to a multigene family and different members may play different roles in different tissues. NCED is well represented on the Wheat Genome Array, with 12 NCED unigenes from various abiotic and biotic stress libraries from leaves, spikes, kernels, and roots. However, none of these NCED transcripts was significantly up-regulated in resistant plants (Table 2). While this suggests that drought/osmotic stress is not present in the resistant leaf samples, further experimentation is needed to verify this inference.

TABLE 3. Genes down-regulated in resistant isolines with $\operatorname{Lr} 34 / Y r 18$ in both Thatcher and Jupateco backgrounds

\begin{tabular}{|c|c|c|c|c|c|c|c|}
\hline \multirow{3}{*}{$\begin{array}{l}\text { Probe set (unigene) } \\
\text { designation }^{\mathrm{a}}\end{array}$} & \multicolumn{6}{|c|}{ Fold differences between $\operatorname{Lr} 34$ and $\operatorname{lr} 34$ transcript levels } & \multirow[b]{3}{*}{ Description } \\
\hline & \multicolumn{2}{|c|}{$\begin{array}{c}\text { Jupateco mock- } \\
\text { inoculated }\end{array}$} & \multicolumn{2}{|c|}{$\begin{array}{c}\begin{array}{c}\text { Thatcher mock- } \\
\text { inoculated }\end{array} \\
\end{array}$} & \multicolumn{2}{|c|}{$\begin{array}{c}\text { Thatcher rust- } \\
\text { inoculated }\end{array}$} & \\
\hline & Tip $^{\mathrm{b}}$ & Base & Tip & Base & Tip & Base & \\
\hline Ta.11025.1.A1_at & & $-1.6^{\mathrm{c}}$ & & -1.5 & & & CPRD2-like FAD-linked oxidoreductase \\
\hline Ta.12091.1.S1_at & -1.6 & -1.6 & -1.7 & -1.5 & & & Predicted protein \\
\hline Ta.13337.1.S1_at & & -1.7 & & -2.1 & & -3.2 & Xyloglucan endotransglycosylase \\
\hline Ta.13337.2.S1_at & & -2.7 & & -4.4 & & -4.2 & Xyloglucan endotransglycosylase \\
\hline
\end{tabular}

a Probe set designations from Affymetrix.

b Tip indicates the apical half of the flag leaf during anthesis; base indicates basal half.

${ }^{\mathrm{c}}$ Indicates the fold change in resistant lines compared with their respective susceptible isolines. Fold change for each cultivar background, inoculation treatment, and leaf tissue was calculated separately with three replicates. Only changes of $\geq 1.5$ fold and $P \leq 0.05$ are shown. 
TABLE 4. Fold changes in gene expression induced by rust infection in leaf tips and bases of resistant and susceptible Thatcher isolines $48 \mathrm{~h}$ after inoculation

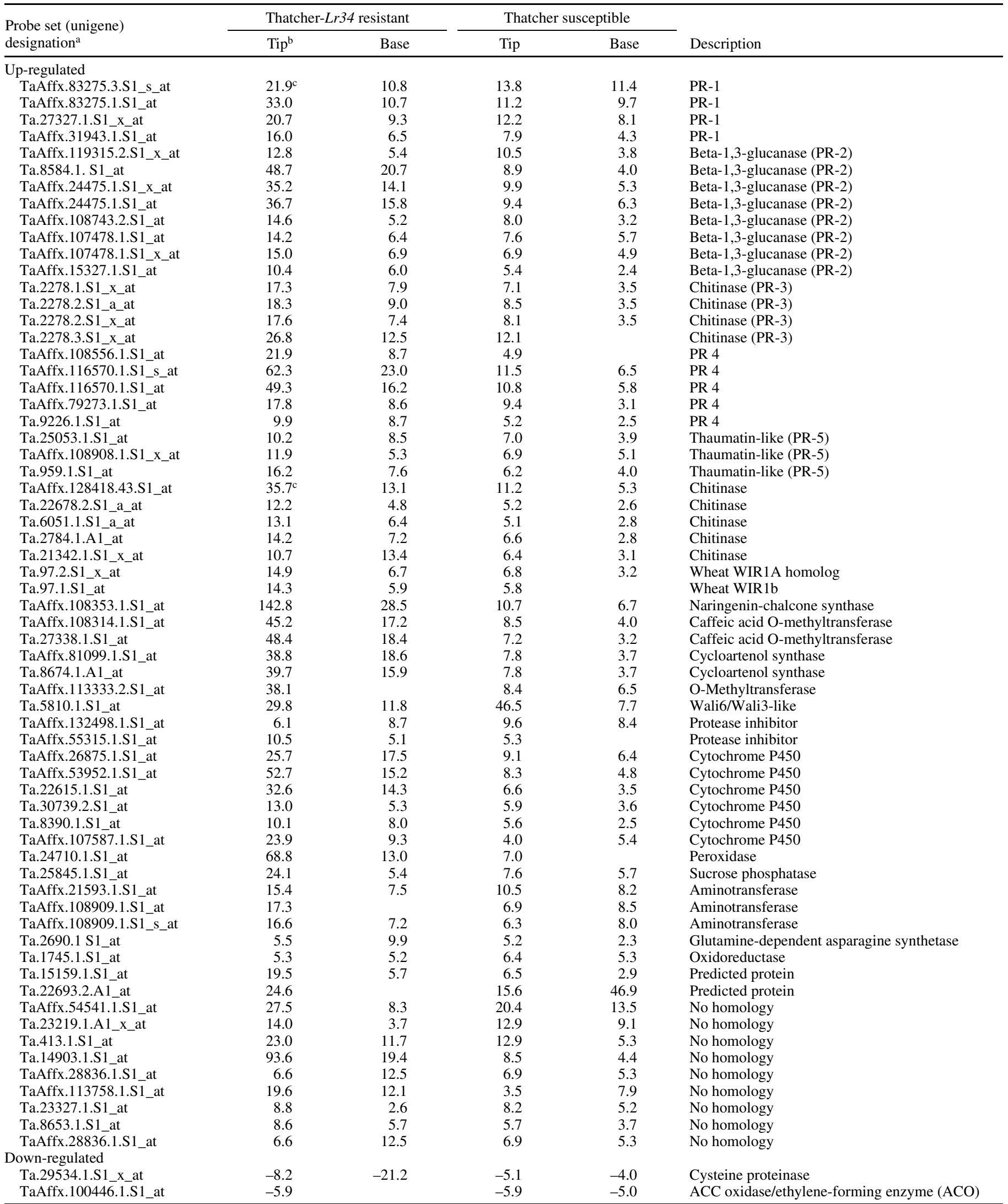

a Probe set designations from Affymetrix. Data include two probe sets for the same predicted gene for Ta.2278.2, TaAffx.116570.1, TaAffx.24475.1, TaAffx.107478.1, TaAffx.108909.1.

${ }^{\mathrm{b}}$ Tip indicates the apical half of the flag leaf during anthesis; base indicates basal half.

${ }^{\mathrm{c}}$ Fold difference increase in expression when inoculated tissue is compared with uninoculated tissue. All changes were significantly different $(P<0.05)$ with at least a fivefold increase in estimated transcript in at least three of four tissues (basal or apical leaf halves of Thatcher or Thatcher-Lr34). 
Another possible explanation for the abiotic stress signature in resistant leaves is some type of signaling or regulatory mutation that results in ectopic expression of a large set of abiotic stress response genes. Abiotic stress genes are regulated by several types of stress-responsive cis-acting elements including ABAresponsive elements (ABRE), cold- and dehydration-responsive elements (DRE), NACR, MYBR, MYCR, and several others (61). We identified three up-regulated transcription factors in resistant plants, including one NAC transcription factor (TaAffx.122104.1) and one zinc finger protein (TaAffx.98394.1). NAC transcription factors and zinc finger proteins can be dehydration- and osmotic stress-responsive in Arabidopsis (61). Other potential signaling or regulatory proteins included three LTPs and a protein phosphatase. Any of these could be involved in generating the abiotic stress signature either upstream or downstream in a signaling cascade. On the other hand, it is possible that no transcriptional change would be observed for a key regulatory protein if the protein was regulated posttranscriptionally or a mutation altered its function or activity.

In order to focus on genes with a possible functional role in resistance, we reasoned that key transcripts should be significantly up-regulated or down-regulated in both the tips and the bases of resistant leaves. Therefore, we shortened the list of genes in Table 2 by requiring that genes be up-regulated in resistant plants in both the mock-inoculated leaf tips and bases. Only five transcripts fit these criteria.

Ta.6567.3 (Fig. 2C) has homology to Arabidopsis droughtinduced protein Di19 and cotton ovule fiber protein $\mathrm{Fb} 2$. Gosti et al. (17) reported that Di19 responded to drought in an ABAindependent manner. The function of this protein is unknown. It did not maintain the correlation between expression and resistance in the rust-inoculated plants, which suggests it may not be a key part of the resistance response.

Ta.14836.1 (Fig. 2D) is of interest because it is the most highly and consistently up-regulated gene in resistant leaf bases, both pre- and post-challenge (Table 2). The sequence for this gene matched nothing in sequence databases. TaAffx.64112.1 showed a modest but consistent up-regulation in resistant leaf tips and bases. It has high homology to a rice predicted protein, but the function is unknown. More work is needed on these two proteins.

Ta.28327.1 (Fig. 2E) was consistently expressed more highly in resistant leaf tips than in bases, which mirrors the Lr34/Yr18 resistance phenotype. It is a type 2 nonspecific LTP that is wellcharacterized structurally (9), but little is known of its biological role. A closely related barley homolog is aleurone-specific (20). LTPs mediate the transfer of phospholipids between membranes and may have a role in vesicle fusion and secretion. LTPs are involved in many signaling processes (3) and certain nonspecific LTPs have been shown to affect pathogenic microbes when expressed in transgenic plants or in vitro $(37,39)$. Many LTPs are pathogen-inducible and have recently been included in the PR proteins as a new class, PR-14 (57). Another two LTPs (Ta.13070.1 and Ta.13070.2) were up-regulated by $L r 34 / Y r 18$ only in leaf tips. They are homologous to a family of type 1 nonspecific LTPs from barley that are expressed in a variety of tissues, including the spike, and the expression of some of these genes is affected by cold treatment and pathogen infection (34, 35). Transcripts of very similar LTPs were found to be increased by both salicylic acid and methyl-jasmonate application to young wheat seedlings (29). Considering the variety of possible functions of these proteins and their expression patterns, LTPs are good candidates for a functional role in resistance mediated by Lr34/Yrl8.

Ta.13183.1 (Fig. 2F) was one of the most highly up-regulated transcripts in leaf tips as observed with two different probe sets for this predicted gene, Ta.13183.1.S1_s_at and Ta.13183.1.S1_x_at. The first probe set detected no significant Lr34-regulated differences transcript levels in leaf bases (Fig. 2F,
Table 2) while the second probe set detected only small (less than twofold) differences in leaf bases. The predicted gene has very high identity with a cold-regulated protein in wheat (WCor18) and barley (tma-ap3). It is a member of the highly conserved phosphatidylethanolamine binding protein family, members of which are associated with control of flowering time in both dicots and monocots (6). Considering the possible involvement in developmental signaling and the large up-regulation of this transcript, it is another good candidate for a functional role in the resistance conferred by Lr34/Yrl8.

Bossolini et al. (4) used a comparative mapping approach to identify candidate genes in the $L r 34 / Y r 18$ region. They speculated that pectate lyases might play a central role in resistance conferred by $\operatorname{Lr} 34 / \mathrm{Yr} 18$ by modifying the cell wall. We did find large transcriptional up-regulation of some putative cell wall modifying enzymes such as xyloglucan endotransglycosylase (Ta.13337.1 and Ta.13337.2) and $\beta$-D-glucan glucohydrolase (Ta.27751.5). Xyloglucan endotransglycosylase deserves special mention for the significant down-regulation in resistant leaf bases (Table 3), which suggests both positive and negative regulatory signals associated with resistance. In any case, we did not find any significantly and consistently up-regulated pectate lyase transcripts in resistant plants. This does not eliminate pectate lyase as a candidate gene since we were not able to verify that the specific candidate gene is represented on the wheat array. Likewise, we did not find expression changes in $\beta 1$-proteasome subunits, which were speculated to be involved with resistance conferred by Lr46/Yr29 (41). In this case, we were able to verify that a $\beta 1$ proteasome subunit gene (Os06g04800) identified by Lagudah et al. (25) from the orthologous rice region (chromosome 6S) was represented on the wheat array (Ta.3303.1).

The broad spectrum of resistance and lack of race specificity of Lr34/Yrl8 are reminiscent of SAR. SAR is a form of induced resistance that is associated with elevated expression of typical PR proteins prior to local challenge by a pathogen $(11,57)$. Although the defense function of each PR protein has not been clearly established, it is thought that SAR operates through the joint action of multiple PR proteins $(11,57)$. SAR can be induced by pathogen attack in another part of the plant or by chemical inducers such as salicylic acid (SA) or BTH $(11,16,29)$. If $\operatorname{Lr} 34$ somehow induced the expression of proteins associated with SAR prior to pathogen challenge, this could explain the nonspecific resistance observed, but this did not appear to be the case. In our experiments, typical PR proteins were not significantly up-regulated in mock-inoculated resistant leaves (Fig. 2I to L). It was only after inoculation that PR genes were up-regulated in both Thatcher and Thatcher-Lr34 (Table 4). In addition, the expression levels of wheat chemically induced genes associated with SAR (16) were not up-regulated in mock-inoculated lines with Lr34/Yrl8 (Table 2).

Induced systemic resistance (ISR) is similar to SAR in that it confers broad spectrum resistance to pathogens $(5,58)$. It is inducible by plant growth promoting rhizobacteria or by application of chemicals such as $\beta$-amino-butyric acid (55). ISR is characterized by the expression of jasmonic acid and ethylene-responsive defense proteins after pathogen challenge $(5,57)$. However, ISR is not associated with changes in gene expression prior to local challenge (58). This differs from our results in which we found large changes in gene expression patterns without pathogen challenge (Table 2). However, it is still possible that Lr34/Yr18 has a role in defense gene priming similar to ISR. After rust inoculation, both resistant and susceptible flag leaves expressed essentially the same set of PR proteins (Table 4), but expression was often higher in resistant leaves (Fig. 2J to L). This is exemplified by several related PR-3-type chitinases (Ta.2278.1, Ta.2278.2, and Ta.2278.3) that were all up-regulated two- to threefold higher in inoculated resistant leaf tips and bases compared with susceptible leaves (Fig. 2J). Other transcripts showed 
patterns of enhanced expression only in the resistant leaf tips (Fig. $2 \mathrm{~K}$ and $\mathrm{L}$ ). As a group, these defense gene expression patterns correlated well with the resistance phenotype associated with Lr34/Yr18. Further experiments using multiple time points are needed to test this priming hypothesis.

Although the objective of this study was to characterize Lr34/Yr34, this study also is an important contribution in identifying wheat genes that are differentially regulated by rust infection. While rust-inoculated material was only examined from the Thatcher isolines, comparisons of inoculated to mock-inoculated in both halves of the flag leaves and both the Thatcher-Lr34 and Thatcher lines should provide a reliable list of genes induced by rust inoculation (Table 4). Examples include many genes encoding typical PR proteins, enzymes involved in phenylpropanoid biosynthesis, and enzymes involved in detoxification of various metabolites.

Two genes were highly down-regulated by rust infection. One gene showed homology to cysteine proteinases (Ta.29534.1.S1_x_at). The most similar proteinases in GenBank for which functions have been associated are involved in senescence $(1,36)$. The other down-regulated gene (TaAffx.100446.1.S1_at) was predicted to code for ACC oxidase, an enzyme involved in ethylene biosynthesis. More information is required on the regulation of these genes to determine whether their down-regulation is an outcome of host defense signaling or specifically regulated by the leaf rust fungus. The inhibition of these proteins by the pathogen may inhibit cell death or senescence and contribute to the classic "green island" effect surrounding pustules in a susceptible interaction.

The present study provided an initial picture of the function and molecular effects of an important adult-plant, durable, slow rusting gene that has become widely used. Since the gene expression patterns associated with $\operatorname{Lr34/Yr18}$ do not fit typical $R$-gene mediated defense responses or previously described disease resistance pathways, it appears that Lr34/Yrl8 has a novel mode of action involving increased expression of a set of abiotic stress or seed maturation genes not usually associated with pathogen defense reactions. The enhanced expression of one or more of these gene products may directly make the leaf more resistant to rust fungi. Another possibility is that these genes create an environment in the leaf in which the typical defense responses to rust infection are primed and occur more strongly or rapidly after infection. An unexpected finding was the vast difference in gene expression pattern between leaf tips and bases. A comprehensive model of the mechanism of $\operatorname{Lr} 34 / Y r 18$ will have to explain that difference.

One important use of the characteristic signature of $\mathrm{Lr} 34 / \mathrm{Yr} 18$ will be in comparisons with other slow rusting genes. Genes like Lr46/Yr29 are phenotypically very similar to $\operatorname{Lr} 34 / \operatorname{Yr} 18(41,52)$ and may share similar modes of action. The $S r 2$ adult-plant stem rust resistance gene also shares some similarities such as durability, race nonspecificity, and association with a necrotic symptom in unchallenged tissue (24). Lr34/Yr18, Lr46/Yr29, and $S r 2$ have been incorporated in many wheat varieties targeted for the developing world by the International Maize and Wheat Improvement Center (CIMMYT, Mexico, D.F.) and are also present in many cultivars grown in developed countries $(13,24,51)$. The increasingly widespread dependence on these slow rusting genes raises concerns whether we may become overly dependent on one mechanism of resistance.

Another important benefit of a better understanding of the mechanism of resistance of $\operatorname{Lr} 34 / \mathrm{Yr} 18$ is the opportunity for fine tuning the resistance response. The list of genes up-regulated in plants with $L r 34 / Y r 18$ is long. It is possible that a small subset of those genes is determinative for resistance and the others are unnecessary or even harmful. Singh and Huerta-Espino (49) documented a $5.9 \%$ lower grain yield in Jupateco $73 \mathrm{R}$ than in Jupateco $73 \mathrm{~S}$ when rust was controlled with fungicides. A portion of this yield decrease could be due to leaf tip necrosis or other side effects of the resistance conferred by Lr34/Yrl8. It might be possible to eliminate or reduce the unwanted negative side effects of $L r 34 / Y r 18$ by down-regulating particular dispensable genes. It might also be possible to increase the effectiveness of $L r 34 / Y r 18$ by altering the expression of particular essential genes.

\section{ACKNOWLEDGMENTS}

This is contribution no. 06-340-J from the Kansas Agricultural Experiment Station. The Affymetrix wheat GeneChips were processed and analyzed in the KSU Gene Expression Facility, supported by NSF Major Research Instrumentation grant DBI-0421427. We thank M. Deshpande and N. Weng for technical support and statistical support; J. Kolmer for providing seed of Thatcher isolines; and R. Singh for providing Jupateco isolines. Mention of a trademark or a proprietary product does not constitute a guarantee or warranty of the product by the U.S. Department of Agriculture, and does not imply its approval to the exclusion of other products that may also be suitable.

\section{LITERATURE CITED}

1. Asp, T., Bowra, S., Borg, S., and Holm, P. B. 2004. Cloning and characterization of three groups of cysteine protease genes expressed in the senescing zone of white clover (Trifolium repens) nodules. Plant Sci. 167:825-837.

2. Bai, J., Choi, S. H., Ponciano, G., Leung, H., and Leach, J. E. 2000. Xanthomonas oryzae pv. oryzae avirulence genes contribute differently and specifically to pathogen aggressiveness. Mol. Plant-Microbe Interact. 13:1322-1329.

3. Blein, J.-P., Coutos-Thévenot, P., Marion, D., and Ponchet, M. 2002. From elicitins to lipid-transfer proteins: A new insight in cell signaling involved in plant defense mechanisms. Trends Plant Sci. 17:293-296.

4. Bossolini, E., Krattinger, S., and Keller, B. 2006. Development of simple sequence repeat markers specific for the Lr34 resistance region of wheat using sequence information from rice and Aegilops tauschii. Theor. Appl. Genet. 113:1049-1062.

5. Bostock, R. M. 2005. Signal crosstalk and induced resistance: Straddling the line between cost and benefit. Annu. Rev. Phytopathol. 43:545-580.

6. Chardon, F., and Damerval, C. 2005. Phylogenomic analysis of the PEBP gene family in cereals. J. Mol. Evol. 61:579-590.

7. Collett, H., Shen, A., Gardner, M., Farrant, J. M., Denby, K. J., and Illing, N. 2004. Towards transcript profiling of desiccation tolerance in Xerophyta humilis: Construction of a normalized $11 \mathrm{k} \mathrm{X}$. humilis cDNA set and microarray expression analysis of 424 cDNAs in response to dehydration. Physiol. Plant. 122:39-53.

8. Dal Bosco, C., Busconi, M., Govoni, C., Baldi, P., Stanca, A. M., Crosatti, C., Bassi, R., and Cattivelli, L. 2003. Cor gene expression in barley mutants affected in chloroplast development and photosynthetic electron transport. Plant Physiol. 131:793-802.

9. Douliez, J. P., Pato, C., Rabesona, H., Molle, D., and Marion, D. 2001. Disulfide bond assignment, lipid transfer activity and secondary structure of a 7-kDa plant lipid transfer protein, LTP2. Eur. J. Biochem. 268:14001403.

10. Drijepondt, S. C., and Pretorius, Z. A. 1989. Greenhouse evaluation of adult-plant resistance conferred by the gene Lr34 to leaf rust of wheat. Plant Dis. 73:669-671.

11. Durrant, W. E., and Dong, X. 2004. Systemic acquired resistance. Annu. Rev. Phytopathol. 42:185-209.

12. Dyck, P. L. 1987. The association of a gene for leaf rust resistance with the chromosome 7D suppressor of stem rust resistance in common wheat. Genome 29:467-469.

13. Dyck, P. L. 1991. Genetics of adult-plant leaf rust resistance in 'Chinese Spring' and 'Sturdy' wheats. Crop Sci. 31:309-311.

14. Gana, J. A., Sutton, F., and Kenefick, D. G. 1997. cDNA structure and expression patterns of a low-temperature-specific wheat gene tacr7. Plant Mol. Biol. 34:643-650.

15. German, S. E., and Kolmer, J. A. 1992. Effect of gene Lr34 in the enhancement of resistance to leaf rust of wheat. Theor. Appl. Genet. 84:97-105.

16. Görlach, J., Volrath, S., Knauf-Beiter, G., Hengy, G., Beckhove, U., Kogel, K.-H., Oostendorp, M., Staub, T., Ward, E., Kessmann, H., and Ryals, J. 1996. Benzothiadiazole, a novel class of inducers of systemic acquired resistance, activates gene expression and disease resistance in wheat. Plant Cell 8:629-643.

17. Gosti, F., Bertauche, N., Vartanian, N., and Giraudat, J. 1995. Abscisic acid-dependent and -independent regulation of gene expression by progressive drought in Arabidopsis thaliana. Mol. Gen. Genet. 246:10-18. 
18. Ibrahim, A. F., Hedley, P. E., Cardle, L., Kruger, W., Marshall, D. F., Muehlbauer, G. J., and Waugh, R. 2005. A comparative analysis of transcript abundance using SAGE and Affymetrix arrays. Funct. Integr. Genomics 5:163-174.

19. Imai, R., Koike, M., Sutoh, K., Kawakami, A., Torada, A., and Oono, K. 2005. Molecular characterization of a cold-induced plasma membrane protein gene from wheat. Mol. Genet. Genomics 274:445-453.

20. Kalla, R., Shimamoto, K., Potter, R., Nielsen, P. S., Linnestad, C., and Olsen, O. A. 1994. The promoter of the barley aleurone-specific gene encoding a putative $7 \mathrm{kDa}$ lipid transfer protein confers aleurone cellspecific expression in transgenic rice. Plant J. 6:849-860.

21. Koike, M., Takezawa, D., Arakawa, K., and Yoshida, S. 1997. Accumulation of $19-\mathrm{kDa}$ plasma membrane polypeptide during induction of freezing tolerance in wheat suspension-cultured cells by abscisic acid. Plant Cell Physiol. 38:707-716.

22. Kolmer, J. A. 1996. Genetics of resistance to wheat leaf rust. Annu. Rev. Phytopathol. 34:435-455.

23. Kolmer, J. A., Long, D. L., and Hughes, M. E. 2005. Physiologic specialization in Puccinia triticina on wheat in the United States in 2003. Plant Dis. 89:1201-1206.

24. Kota, R., Spielmeyer, W., McIntosh, R. A., and Lagudah, E. S. 2006. Fine genetic mapping fails to dissociate durable stem rust resistance gene $\mathrm{Sr} 2$ from pseudo-black chaff in common wheat (Triticum aestivum L.). Theor. Appl. Genet. 112:492-499.

25. Lagudah, E. S., McFadden, H., Singh, R. P., Huerta-Espino, J., Bariana, H. S., and Spielmeyer, W. 2006. Molecular genetic characterization of the Lr34/Yr18 slow rusting resistance gene region in wheat. Theor. Appl. Genet. 114:21-30.

26. Leach, J. E., Vera-Cruz C. M., Bai, J. F., and Leung, H. 2001. Pathogen fitness penalty as a predictor of durability of disease resistance genes. Annu. Rev. Phytopathol. 39:187-224.

27. Leonard, K. J. 1997. Modeling gene frequency dynamics. Pages 211-230 in: The Gene-for-Gene Relationship in Plant-Parasite Interactions. I. R. Crute, E. B. Holub, and J. J. Burdon, eds. CAB International, London.

28. Lin, K. C., Bushnell, W. R., Szabo, L. J., and Smith, A. G. 1996. Isolation and expression of a host response gene family encoding thaumatin-like proteins in incompatible oat-stem rust fungus interactions. Mol. PlantMicrobe Interact. 9:511-522.

29. Lu, Z. X., Guadet, D., Puchalski, B., Despins, T., Frick, M., and Laroche, A. 2006. Inducers of resistance reduce common bunt infection in wheat seedlings while differentially regulating defense-gene expression. Physiol. Mol. Plant Pathol. 67:138-148.

30. Lui, J. Q., and Kolmer, J. A. 1998. Genetics of stem rust resistance in wheat cvs. Pasqua and AC Taber. Phytopathology 88:171-176.

31. McDonald, B. A., and Linde, C. 2002. Pathogen population genetics, evolutionary potential, and durable resistance. Annu. Rev. Phytopathol. 40:349-379.

32. McIntosh, R. A. 1992. Close genetic linkage of genes conferring adultplant resistance to leaf rust and stripe rust in wheat. Plant Pathol. 41:523527.

33. McIntosh, R. A., Wellings, C. R., and Park, R. F. 1995. Wheat Rusts: An Atlas of Resistance Genes. CSIRO Publications, East Melbourne, Victoria, Australia.

34. Molina, A., Diaz, I., Vasil, I. K., Carbonero, P., and Garcia-Olmedo, F. 1996. Two cold-inducible genes encoding lipid transfer protein LTP4 from barley show differential responses to bacterial pathogens. Mol. Gen. Genet. 252:162-168.

35. Molina, A., and Garcia-Olmedo, F. 1993. Developmental and pathogeninduced expression of three barley genes encoding lipid transfer proteins. Plant J. 6:983-991.

36. Naito, Y., Fujie, M., Usami, S., Murooka, Y., and Yamada, T. 2000. The involvement of a cysteine proteinase in the nodule development in Chinese milk vetch infected with Mesorhizobium huakuii subsp. rengei. Plant Physiol. 124:1087-1096.

37. Patkar, R. N., and Chattoo, B. B. 2006. Transgenic indica rice expressing ns-LTP-like protein shows enhanced resistance to both fungal and bacterial pathogens. Mol. Breed. 17:159-171.

38. Piffanelli, P., Zhou, F., Casais, C., Orme, J., and Jarosch, B. 2002. The barley MLO modulator of defense and cell death is responsive to biotic and abiotic stress stimuli. Plant Physiol. 129:1076-1085.

39. Regente, M. C., Giudici, A. M., Villalain, J., and de la Canal, L. 2005. The cytotoxic properties of a plant lipid transfer protein involve membrane permeabilization of target cells. Lett. Appl. Microbiol. 40:183-189.

40. Roosens, N. H. C. J., Thu, T. T., Iskandar, H. M., and Jacobs, M. 1998.
Isolation of the ornithine- $\delta$-aminotransferase cDNA and effect of salt stress on its expression in Arabidopsis thaliana. Plant Physiol. 117:263271.

41. Rosewarne, G. M., Singh, R. P., Huerta-Espino, J., William, M., Bouchet, S., Cloutier, S., McFadden, H., and Lagudah, E. S. 2006. Leaf tip necrosis, molecular markers and $\beta 1$-proteasome subunits associated with the slow rusting resistance genes Lr46/Yr29. Theor. Appl. Genet. 112:500508.

42. Rubiales, D., and Niks, R. E. 1995. Characterization of Lr34, a major gene conferring nonhypersensitive resistance to wheat leaf rust. Plant Dis. 79:1208-1212.

43. Schafer, J. F., and Roelfs, A. P. 1985. Estimated relation between numbers of urediniospores of Puccinia graminis f. sp. tritici and rates of occurrence of virulence. Phytopathology 75:749-750.

44. Seo, M., and Koshiba, T. 2002. Complex regulation of ABA biosynthesis in plants. Trends Plant Sci. 7:41-48.

45. Singh, R. P. 1992. Association between gene Lr34/Yr18 for leaf rust resistance and leaf tip necrosis in wheat. Crop Sci. 32:874-878.

46. Singh, R. P. 1992. Genetic association of leaf rust resistance gene Lr34 with adult plant resistance to stripe rust in bread wheat. Phytopathology 82:835-838.

47. Singh, R. P. 1993. Genetic association of gene $B d v 1$ for tolerance to barley yellow dwarf virus with genes $\operatorname{Lr} 34$ and $\mathrm{Yr} 18$ for adult plant resistance to rusts in bread wheat. Plant Dis. 77:1103-1106.

48. Singh, R. P., and Gupta, A. K. 1992. Expression of wheat leaf rust resistance gene $L r 34$ in seedlings and adult plants. Plant Dis. 76:489-491.

49. Singh, R. P., and Huerta-Espino, J. 1997. Effect of leaf rust gene Lr34/Yr18 on grain yield and agronomic traits of spring wheat. Crop Sci. 37:390-395.

50. Singh, R. P., and Huerta-Espino, J. 2003. Effects of leaf rust resistance gene Lr34 on components of slow rusting at seven growth stages in wheat. Euphytica 129:371-376.

51. Singh, R. P., Huerta-Espino, J., and William, H. M. 2005. Genetics and breeding for durable resistance to leaf and stripe rusts in wheat. Turk. J. Agric. For. 29:121-127.

52. Singh, R. P., Mujeeb-Kazi, A., and Huerto-Espino, J. 1998. Lr46: A gene conferring slow rusting resistance to leaf rust in wheat. Phytopathology 88:890-894.

53. Spielmeyer, W., McIntosh, R. A., Kolmer, J., and Lagudah, E. S. 2005. Powdery mildew resistance and $\operatorname{Lr} 34 / \mathrm{Yr} 18$ genes for durable resistance to leaf and stripe rust cosegregate at a locus on the short arm of chromosome 7D of wheat. Theor. Appl. Genet. 111:731-735.

54. Tan, B. C., Schwartz, S. H., Zeevart, J. A. D., and McCarty, D. R. 1997. Genetic control of abscisic acid biosynthesis in maize. Proc. Natl. Acad. Sci. USA 94:12235-12240.

55. Ton, J., Gabor, J., Toquin, V., Flors, V., Iavicoli, A., Maeder, M. N., Métraux, J.-P., and Mauch-Mani, B. 2005. Dissecting the $\beta$-aminobutyric acid-induced priming phenomenon in Arabidopsis. Plant Cell 17:987-999.

56. Tremblay, K., Ouellet, F., Fournier, J., Danyluk, J., and Sarhan, F. 2005. Molecular characterization and origin of novel bipartite cold-regulated ice recrystallization inhibition proteins from cereals. Plant Cell Physiol. 46:884-891.

57. van Loon, L. C., Rep, M., and Pieterse, C. M. J. 2006. Significance of inducible defense-related proteins in infected plants. Annu. Rev. Phytopathol. 44:135-162.

58. Verhagen, B. W. M., Glazebrook, J., Zhu, T., Chang, H.-S., van Loon, L. C., and Pieterse, C. M. J. 2004. The transcriptome of rhizobacteriainduced systemic resistance in Arabidopsis. Mol. Plant-Microbe Interact. 17:895-908.

59. Wolter, M., Hollricher, K., Salamini, F., and Schulze-Lefert, P. 1993. The mlo resistance alleles to powdery mildew infection in barley trigger a developmentally controlled defense mimic phenotype. Mol. Gen. Genet. 239:122-128.

60. Yamada, M., Morishita, H., Urano, K., Shiozaki, N., YamaguchiShinozaki, K., Shinozaki, K., and Yoshiba, Y. 2005. Effects of free proline accumulation in petunias under drought stress. J. Exp. Bot. 56:1975-1981.

61. Yamaguchi-Shinozaki, K., and Shinozaki, K. 2006. Transcriptional regulatory networks in cellular responses and tolerance to dehydration and cold stresses. Annu. Rev. Plant Biol. 57:781-803.

62. Zhao, T.-Y., Martin, D., Meeley, R. B., and Downie, B. 2004. Expression of the maize GALACTINOL SYNTHASE gene family: II) Kernel abscission, environmental stress and myo-inositol influences transcript accumulation in developing seeds and callus cells. Physiol. Plant. 121:647-655. 